\title{
Understanding The Importance Of Application Of Love Accounting To Tax Reporting And Paying
}

\author{
Wahyuni $^{1)}$, Alimuddin ${ }^{2)}$, Amiruddin*3) \\ 1), Fakultas Ekonomi dan Bisnis, Universitas Muhammadiyah Makassar, \\ 2,3) Fakultas Ekonomi dan Bisnis, Universitas Hasanuddin Makassar \\ *Coresponding Author \\ Email : wahyuniu65@gmail.com
}

\begin{abstract}
This study aims to analyze how to uncover the importance of applying love accounting to tax reporting and payment (Case Study on CV. Citra Panca Mandiri). This type of research uses qualitative, with phenomenological approach. This research was conducted at the CV. Citra Panca Mandiri and Account Representative (AR) At KPP Madya Makassar, the informants consisted of 4 CPM staff, namely 3 people from the accounting division, 1 person from the tax division and 2 informants from KPP Madya Makassar. Data collection techniques used were interviews and documentation. The technique of data analysis consists of data reduction, data presentation, and conclusion. While checking the validity of data using triangulation of sources. Based on the results of data analysis, that it is very important to instill a sense of love in reporting and paying taxes, where by linking between commercial parties having transaction partners who commit fraud, they do not report to the state but they have taken the value of 23 pph on the commercial side and when the commercial party wanting to report a pph 25 will have an impact on paying taxes to countries that cannot be credited. But according to the researcher's view it can be minimized when instilling love, because with love, accounting related to tax reporting and income tax 23 will have an impact on their ethics and morals in reporting and paying taxes. So with a sense of love can be minimized the occurrence of fraud that can be troubling commercial parties.
\end{abstract}

Keywords: Commercial, Fiscus, Income Tax PPH 23, VAT, Love Accounting, Fraud

\section{INTRODUCTION}

In life they have reciprocity for what they get, as well as between companies known as taxpayers and the tax authorities have a reciprocal relationship, where taxpayers will run their business and have obligations to the state, namely paying taxes. As we know the government, which we usually call the state, will exercise its rights to entrepreneurs or anyone who runs a business and is obliged to provide it to the state through tax payments which we usually know as pph 21, pph 23, pph 25, and vat taxes. With the collection of tax payments made by commercial parties, the commercial parties or taxpayers will automatically exercise their rights, namely making tax payments to the state.

Financial statements are reports that can be used as a decision-making tool for companies, but in reality, more than one financial statement is usually made, namely one for the position of owners, investors and creditors and even the government, namely taxes. With the separation of making financial statements, discrimination or irregularities usually arise that make recipients of financial statements worried or suspicious about the fairness in the presentation of financial statements made by management. Therefore, accounting has an important role as a dominant force in capitalism by documenting bootom line profits, wealth accumulation, (Aji Dedi Mulawarman and Ari Kamayanti, 2015). These findings reveal that 
accounting is influenced by secular western culture through education and educators as agents that influence the legitimacy of the state, and this with spiritual values or Islamic values applied will replace a concept that accounting is not only based on capitalism but can be convincing. that can improve the welfare of the community.

Meanwhile, according to McKernan \& Kosmala Maclullich, 2004, McKernan reveals that a more adequate foundation is found in ethics and what makes a crisis in financial reporting occur is the lack of communication and ethics in carrying out their duties. It was also revealed from (Benston \& Hartgraves, 2002), and (Beck \& Wu, 2006), that in this period after the Enron case, accounting regulators around the world were busy working on resuscitation of financial reporting standards and laws. Part of the regulatory response to the Enron scandal is one that must be prevented and not scandalized, therefore each management will make reporting according to the reporting regime. As we know, what caused the crisis in financial reporting was the attitude or morale, it was expressed by McBarnett and Whelan (1992a, 1992b, 1999) (6), (7), (8) (McBarnett, D. and Whelan, nd) , (Shah, 1996), the results of this study recognize that accounting practice has a moral dimension that cannot be eliminated and sees the crisis as basically a crisis of moral authority and judgment. We see accounting regulations as having lost their moral legitimacy power. We consider the modernist response to the crisis of authority offered by the ethical discourse of Habermas, (Habermas, J. (1983), Moralbewusstsein und kommunikatives Handeln et al., 1983) (McKernan \& Kosmala Maclullich, 2004). Given several related views that financial reporting crises can be avoided when instilling a sense of love and justice, the conclusion here is not that love must sweep out mere justice, but that they can work together in a fruitful relationship, so that love can be expressed through justice, and justice. through love (McKernan \& Kosmala Maclullich, 2004).

Talking about love, justice in accounting, this research reveals how important love is that we instill in business activities run by entities, because by instilling a sense of love in it, it is part of one's faith, as we know with the faith that is owned, activities business in the world of entities can run smoothly and even justice can be realized, one of which is in recognizing profits, paying taxes to the state. Talking about the concept of justice according to (Alimuddin, 2017), said that the concept of price based on the value of justice In general, the concept of price based on the value of justice in Islam is cost-plus pricing, contrary to what was said (Antong et al., 2018), saying that accounting practices by state-owned companies are still far from Indonesian values. The earth, air and natural resources contained in the earth of Indonesia belong to the people. Welfare but findings in the community that did not exist from the start the resources managed by the company. The reality of social performance is only in the form of false sustainability because it is still formally legal, only limited to broadcasting and even becomes a tool of corporate hegemony. It does not instill a sense of love in it, so with the existence of accounting practices that actually weaken the situation experienced in the business world, therefore there needs to be Islamic values in it such as ethics in an entity.

Talking about accounting practices today requires a value and ethics in carrying it out, so that it can run according to the rules and can avoid discrimination, therefore there is a need for Islamic guidelines for accountants which are drivers of ethical behavior to comply with Islamic principles. This is especially important in today's volatile business environment and competitive pressures. Muslim accountants can use Islamic ethics as a reference to ensure excellent audit work to comply with Shariah requirements and to provide information needed by society such as by doing khayr (goodness), birr (righteousness), 'adl (balance). and justice), trust (trust), virtue (ihsan) and others. Understanding and applying Islamic ethics contributes to more ethical accounting practices 
(Wahyuni-TD et al., 2018). In addition, with the application of Islamic ethics, it should be applied early when in college, this is supported by (Kamayanti, 2020) who says that vocational education is usually considered a mere producer of labor; the term now commonly known as factory teaching institute, is a misguided concept. The essence of education in every type of study, whether academic or vocational, is the same. It is the transfer of values, knowledge and skills. Thus, the ability to apply accounting knowledge, will increase if students are taught to be contextual and spiritual, not just rationally aware. The creation of applied accounting can only bring prosperity to civilization if accounting is created with values that are in accordance with the beliefs and local wisdom of the wearer. (Carmona \& Ezzamel, 2006) revealed that in accounting research it is necessary to instill religious or spiritual values in it given the lack of academic interest in studying accounting in religious institutions.

With the view related to accounting practices that will produce a positive side and a negative side if it is misused, such as the Enron case which was carried out in the world of accounting practice. From these accounting practices, it will produce information for internal and external parties, one of which is tax which is the topic of this research by linking accounting practices to the government, one of which is tax payments made by entities to the government or the state. With the existence of crime or fraud that occurs in business and daily activities in this world, it can be minimized by instilling a principle: that when we instill a sense of love for ourselves and don't destroy it to damage our dinner plates, that doesn't happen., especially when we have the essence of Islam, namely monotheism or the oneness of God, the act of affirming God as one, absolute and transcendent creator (al-Faruqi, 1986 in Mulawarman).

The principle of worship or worship according to Mulawarman is a form of obedience and submission that culminates in something that is believed to control one's body and soul with mastery whose meaning and essence are unreachable, so that with this they will avoid bad deeds for themselves. The signs of a person's success in achieving the essence of worshiping God can be detected in three conditions. First, humans do not consider what is in their hands as private property, meaning that with this principle they will keep themselves from committing crimes because they think that it belongs to Allah as a place for him to serve. Second, all his activities revolve only around what is commanded by those to whom he serves and avoid what he forbids. Third, do not ensure something for him to do or avoid except by relating it to the will of whom he serves. Referring to the case of gayus tambunan, didal made a mistake that made the government and society worry that gayus had no principles in his life.

According to (Indriasari, 2015) said that from the process of thinking, experience, and contemplation raises a lot of awareness in us that science (accounting) must continue to grow and develop based on the existing reality. Love can provide an all-powerful power to grow accounting as a science that should not be understood according to its standard. Love will be a balance for science (accounting) which is more humanistic and divine. Even when we relate to knowledge (taxes) then the process will give someone the power to stay on track and do things according to the rules by reporting and paying taxes in accordance with the regulated provisions because by doing so they assume that they will not take tax. rights that are not their rights, so that fraud in the business world, both commercial and tax parties will not commit fraud. So great is the meaning of love that is owned in a person then the world will be fine. Because with love, we have implemented ethics in the business world, because with ethics in a person they can avoid the crime that occurs in the business world. Talking about love, here we relate one of the biggest sources of revenue by the government, namely taxes, where taxpayers will contribute to the state, if we associate it with their love 
for themselves, they will carry out their obligations by paying taxes to the state.

This research focuses on construction companies, namely CV. Citra Panca Mandiri which is one of the construction companies that is a pkp and this company will automatically collect taxes and pay taxes. When a person applies love in himself, they will maintain that their faith is not polluted with other things, one of which is committing crimes in the world of taxes and disturbing other parties or even eating rights that are not theirs. And from this also, the taxation party, namely KPP Madya Makassar as a bridge to respond if there are commercial parties or commercial transactions lawab commit fraud or irregularities that occur in the business world. In addition, a tax will protect and be responsible for their duties because they have principles and faith in themselves which means they have instilled a sense of love in themselves and their business activities.

\section{RESEARCH METHODS}

The research approach used is qualitative, namely the data analysis process takes place before the researcher goes to the field, then during the field and after in the field, as stated by Sugiyono (2012) that the analysis has started since it was formulated and explained the problem, before going into the field and continuing. until the writing of the research results. Research approach with phenomenological approach. The phenomenological method is research that focuses on real experiences and describes how other people experience and what it means to them. Phenomenologists believe that in living things, there are various ways to interpret experiences through interactions with other people.

Meanwhile, data analysis according to Bogdan and Biklen (Maleong, 2011) is an effort made by working with data, organizing data, sorting it into manageable units, synthesizing it, searching and finding what can be told to others in a different way. field observations, media interviews with commercial parties regarding the importance of applying love accounting in reporting and paying taxes made by commercial parties to the government, based on this, the tax authorities will follow up with them to overcome fraud committed by the tax payer's opponent.

In this study, it focuses on a phenomenon called social situation which consists of 3 elements, namely place, actor, and activity. Informants in this qualitative study were selected and determined with various considerations and are several parties with certain classifications to facilitate researchers in conducting research, namely: 2 staff from CV. Citra Panca Mandiri Makassar and 2 Account Representatives (AR) KPP Madya Makassar. According to Mamik (2015), there are three main stages in qualitative research, namely observation, data reduction, and selection (determination of focus). Descriptive research analysis technique is to present theoretical concepts and a general description of the object of research. Data analysis was done manually. The researcher explains the phenomenology of the importance of applying accounting to tax reporting and payment which will have an impact on indications of fraud felt by commercial parties and what opinion will be made by the tax authorities in responding to fraud based on data obtained during interviews and selected at the time of observation without adding or subtracting it. The results of the analytical research are to find out the phenomenology, and various facts that occur related to the tax authorities and commercial parties related to the indications made in reporting and payments. 


\section{RESULTS AND DISCUSSION}

Research conducted at the Office of CV. Citra Panca Mandiri and KPP Madya Makassar. By using the interview method. The number of samples that were successfully interviewed were 4 people, namely 2 people from CV. Citra Panca Mandiri, which consists of 1 person from the accounting staff, and 1 tax staff, as well as 2 people from the tax office, namely the Account Representative (AR) of KPP Madya Makassar.

Based on the results of interviews with commercial parties regarding the importance of applying love accounting to reporting and paying taxes made by commercial parties which will have an impact on indications of fraud. In carrying out business activities, taxpayers should have an obligation to report and pay taxes to the state, one of which is the reporting of value added tax or VAT and reporting of PPH 23. become an obstacle during tax reporting, namely every transaction opponent who gets a tax invoice from the CPM, the counterparty is usually slow to provide proof of deduction and even they do not provide it at all, and this is often felt by the entity, therefore it is very troubling for the parties involved. issue an invoice. When we relate it to love-based accounting, where accounting here relates to financial reporting that will be reported by the CPM every year and to make tax reporting and payments there are usually several documents that must be collected which can be used as tax deductions but these documents are usually not obtained because the counterparty does not give from this attitude shows that the counterparty is not responsible for his duties and does not give rights to his opponent. Based on this, there are several things that are discussed in this study to reveal how important it is to apply love accounting in reporting and paying taxes, namely:

\section{a. Love for Commercial View of Tax Reporting and Payment}

Based on the results of interviews conducted with informants from commercial parties or companies where the researchers asked the question, what is the view of the commercial parties about the meaning of love that must be instilled in conducting business activities? Mr. Jamal said that we rarely get to talk about love in the world of entities in the real world, let alone talk about business and payments that must be issued by entities, where entities will pay close attention to what money goes out so that it doesn't come out that is not important to their entity.

Meanwhile, according to Mrs. Febry, talking about the meaning of love that in automatic tax reporting we must be honest, because being honest is part of faith, and when we have faith, whatever we do we will not take what is not our right, especially if it is associated with reporting. taxes paid by the company to the government. Because it is the obligation of the entity to carry out their payments.

Based on the view of the commercial side, this is related to that it is very important to instill a sense of love in tax reporting, whether in tax reporting the counterparty of the entity has given its rights to the entity, so that reporting can run smoothly, and when we associate it with faith or love that we has it been felt by the entity? Based on the researcher's question, Mrs. Arni gave a rebuttal saying that if we saw from several years that most of the transaction counterparties were not honest in giving us their rights, we took the example of proof of withholding income tax 23 which is already our right, but they do not provide an obligation. them to us so that from this we are at a loss because we cannot do a tax credit at the time of reporting pph 25 and this makes taxpayers nervous, namely cpm. So it's very difficult to instill love in business activities, especially for yourself, because when it comes 
to love in accounting, especially reporting and paying taxes that will have an impact on the country, I rarely get it, and most of our opponents mostly make cuts in sales bills but don't deposit them. to the country and in the end will have an impact on us. Meanwhile, Mr. Jamal said that when talking to the opposite party of the transaction to be honest, by instilling a feeling it will automatically have an impact on their faith. Whereas in the business world it is very difficult to find someone who will behave honestly in their obligations.

Based on the results of interviews related to the importance of accounting love that must be applied in the business world, especially with regard to reporting and paying taxes, that in the business world that has been felt by the tax authorities, there is still someone who has an irresponsible attitude in tax reporting, where companies that issue invoices to the counterparty to the transaction but does not get the right in the form of a document or proof of deduction, and this makes the commercial party restless. Based on this, the researcher asked the commercial parties questions to deal with this, what would you like to convey to the parties running the business in it if we relate it to the value of spirituality or love related to reporting and paying taxes which are your responsibility as the party running the business?

According to Mr. Jamal, what he said is actually simple to donate to those who run a business is, don't take what is not your right when you are looking for a life in your business, because by taking a right that is not your right then it will also be taken more than what do you guys get. Likewise with reporting and paying taxes, where the entity is already carrying out business activities in Indonesia, then the right is to file a tax report every year which is known as pph 25, but if you do not report it to the state then we will have a shortage to be used as a tax deduction. Whereas in all religions teach us to do good and be honest in doing something, and if we instill a sense of love, the accounting reported by the company to the state will give goodness to the government, because the income earned by the government will have an impact on the state, and the state. will return to the people.

Meanwhile, according to Mrs. Febry, that we hope that the counterparty of the transaction to timely report to us what is our right without us having to ask, because if we have an Islamic value in us then we will feel calm and even our income will be more blessed. and more by flowing continuously without us realizing it., therefore it is very important if we apply religious values in ourselves, wherever we are.

What if we relate to morals or ethics in reporting and paying taxes according to commercial parties:

According to Mrs. Arni saying that morality or ethics is related to our attitude, if it is related to ethics in religion it is closely related, because someone must have ethics in life, such as don't eat what is not your right, and if we get something then don't take it or in my religion Usually if we get something on the street, we will donate it to the mosque or usually it is also related to the norms or rules that we have to follow, because in my religion there are some rules that must be followed in religion, such as don't relate to people who are not our relatives, don't tell bad things about others. , don't like to spit someone's ugliness. So if I relate the accounting view of love to the ethics section, suppose that is our rule to the state, where the commercial obligation to the state is in reporting VAT taxes, namely making a tax invoice to the buyer, then if we make a purchase of goods or purchase an expedition, we will deduct the income tax. 23 and collect and this is a rule in the business world and the government's obligation to the state.

Meanwhile, Pak Tri said that talking about ethics in Islam in everyday life can't actually be implemented in a business concept, because usually it depends on the person and sometimes someone thinks rationally and what is more important and we return it to the 
human resources whether they will carry out their responsibilities. to ethics in the world of taxes, namely reporting and paying taxes on time. But if we relate ethics in the Islamic world to religious life which must obey the rules according to the advice of the Islamic religion, it has been carried out in human life, and we hope that the existence of Islamic values that we have can be a driving force not to commit fraud or deviations that can disturb each other. other.

Based on the results of interviews conducted by commercial parties, that we realize that in the business world its nature is to seek profit, and from the profits we get, we will report taxes to the state, and if tax reporting to the state is misinterpreted by the counterparty, as in the example above. . The researcher concludes that there is a need for spiritual values that we must have such as not taking rights that are not ours, being responsible and maintaining the good name of the company when conducting business activities. Where the view of commercial parties says that there are still many transaction partners who do not give them their rights and it is hoped that there will be assistance such as tax parties who are third parties and parties who have the power to provide direction to counterparties who behave in saving.

\section{b. Love for Fiskus' View of Tax Reporting and Payment}

Based on the results of interviews that have been conducted with the tax authorities, where in reporting and paying taxes made by commercial parties in carrying out their obligations as taxpayers who run their business in any country, including in Makassar, they will make tax distribution and reporting to the state or tax. The thing that worries them in running their business is that transaction partners find it difficult to provide tax deduction documents to their companies, and according to commercial parties that by doing this if there is no love or faith or ethics that are owned it will continue to happen and from this opinion, what is the view as a tax party who is a third party and who is a bridge to as a party who will help commercial parties if the opposing party shows indications of fraud or laying on the taxpayer.

According to AR, based on this, it is better for commercial parties to be open to us or ask us about what happened, so we will follow up by sending a letter and finding out the cause, because with this, the tax party will actually be harmed because the foreign party of the transaction delays payments to the state and this will be followed up. If I associate it with the view of love, surely we realize that love brings happiness to anyone, if the tax rules that we issue will have a bad impact on the opposing party or the commercial party, then we as a party that can protect taxpayers, we will always help if we get a report. Because with us protecting taxpayers, we can provide happiness and taxpayers will not be anxious anymore.

Meanwhile, Ar 2 said that I agree with what our colleagues said, that love in the business world helps taxpayers to accommodate their concerns, we will try to help them and there is a service to complain to us regarding the behavior of the transaction opponent who commits fraud. fraud or irregularities to commercial parties.

Based on this view, what if the counterparty who commits fraud turns out to be wrong in responding or even not making payments, who is to blame for the negligence committed by the counterparty and what is the view of the tax authorities?

Based on this question, AR1 responds that if the person making the deductions by the opposing party and the opposing party if it is traced does not make a payment then we will conduct further investigation and will write and even issue a sp2dk letter to check the consequences of the mistake made and of course payment will be made plus an additional payment. payment of fines to the counterparty and not to blame for the person who issued 
the tax invoice. Meanwhile, AR2 says that if we relate it to the application of love accounting, as we know in accounting here it is closely related to financial reporting, where financial reporting reported by the counterparty will have an impact on tax payments to the state, and if tax payments to the state have indications fraud committed will be investigated further and will assist commercial parties by providing a consultation room regarding indications of fraud, from this, fraud will be avoided and tax payments to the state will also have an impact on happiness, because with love applied it will make the priest or happiness in his world, because we know one of the biggest sources of revenue in our country is taxes. Therefore, we as a party can be used as a third party to protect it, if anyone makes corrections or consultations, we will follow up.

Based on the results of interviews with the tax authorities, the researchers concluded that by instilling a sense of love in it, it will make taxpayers happy. So that the unrest experienced by commercial parties will be followed up and help to reduce taxpayers who make irregularities. as we know that love creates a positive energy that will have an impact on taxpayers and no one is harmed and we as a third party will help commercial parties and will provide a consultation room for those who want to report indications of fraud in reporting and paying taxes to the public. the state and of course the tax authorities will follow up. Based on the view of the tax authorities, it means that they have implemented love and justice in the world of tax authorities by providing follow-up and ready to accommodate and open a room for consultation and discussion if there is fraud or indications that will harm other parties.

This is supported by (Hidayatulloh \& Mutingatun, 2020), showing that this study obtained the result that the more people love money, the more one's ethics will affect tax fraud. Conversely, individuals who have a low love of money will have high ethics so that these individuals will carry out their obligations to pay taxes (Kirchler, Hoelzl, \& Wahl, 2008, Farhan M. Helmy, 2019).

Another factor that can trigger taxpayers to avoid taxes is the religiosity factor (Rosianti \& Mangoting, 2014)); love of money (Basri, 2014), tax fraud is considered reasonable because it is carried out by parties who value or instill a high love of money. In addition, the love of money and ethical behavior can not be separated from gender. This is as expressed that women tend not to prioritize money compared to men, (Budiarto et al., 2018) shows that the taxation material provided does not yet have an ethical element. Teaching is only technical skills without taking into account the importance of ethics.

\section{CONCLUSION}

Commercial is one of the taxpayers who carry out their obligations in conducting business activities, namely by reporting and paying taxes to the state. In connection with these activities, there are still many commercial counterparties who have counterparties who collect income tax and VAT but they do not exercise their rights, namely paying and reporting taxes and providing proof of deduction to taxpayers, this makes commercial parties and the tax authorities nervous. answer these questions by giving a complaint or complaining at the middle kpp, to be followed up, then from this research it also illustrates that to detect or minimize fraud, it can be done by applying love in accounting to the reporting, in addition to instilling a sense of love automatically will automatically result in an energy that will have an impact on reporting and paying taxes, the more someone carries out their duties in paying taxes, the better it is to create love, because with love in accounting is related to financial reporting, where financial reporting is made $\mathrm{n}$ as the basis for making tax payments, but there is also another view that is captivating about love, that 
the more a person loves money, the more they will affect a person's ethics, namely delaying, saving and manipulating related to tax reporting. If we relate to several cases that occurred, such as the case of Enron and Gayus who committed fraud in financial and tax reporting which harmed investors and the state because they made tax deductions and recognized as much profit as possible, even though they committed fraud. Based on this, that in the world of accounting education we see that most people commit fraud so that it makes us think why with our education, which is increasingly unreasonable, always commits fraud or irregularities.

After doing a search, it turns out that what makes this happen is because there is no spiritual value and the value of love that is instilled in the activities carried out by any party. The implications in this study provide benefits in the development of agency theory and interests in the world of taxation with the study of this theory, it will be one of the ways to trigger or reveal why that in the world of taxation what must be carried out by commercial parties, namely reporting and paying taxes must be done and when If it is associated with a sense of love in it, it will avoid deviations in it. While the Practical Implications provide benefits for commercial parties to prove that with a faith that humans will obey in paying and reporting taxes, especially if it is supported by the opposite party, the transaction and when it is violated then there is an intermediary, namely the tax authorities who will help to write letters to the opposing parties in commercial transactions and this is based on the fact that a tax officer has ethics and faith in carrying out his duties as the highest party between commercial and legal parties. $\mathrm{n}$ transactions.

\section{REFERENCES}

Aji Dedi Mulawarman dan Ari Kamayanti. (2015). Towards Islamic Accounting Anthropology: how secular anthropology reshaped accounting in Indonesia. Journal of Islamic Accounting and Business Research, https://doi.org/10.1108/ JIABR-02-2015-0004 Permanent.

Alimuddin, A. (2017). Merangkai Konsep Harga Jual Berbasis Nilai Keadilan Dalam Islam. EKUITAS (Jurnal Ekonomi Dan Keuangan), 15(4), 523. https://doi.org/10.24034/j25485024.y2011.v15.i4.2316

Al Faruqi, IR 1986, Al Tawhid: Its Implications for Thought and Life, 4th edition. International Institute of Islamic Thought, Virginia.

Antong, A., Hasanuddin, B., Said, D., Alimuddin, A., \& Filho, F. de S. P. (2018). Critical Study of the Accounting Practices of Indonesians State-Owned Enterprises. International Journal of Advanced Engineering Research and Science, 5(8), 200-210. https://doi.org/10.22161/ijaers.5.8.25

Basri, Y. M. (2014). Efek moderasi religuisitas dan gender terhadap hubungan etika uang dan kecurangan pajak. SNA 17 Mataram, Lombok, 1-23.

Beck, P. J., \& Wu, M. G. H. (2006). Learning by Doing and Audit Quality*. Contemporary Accounting Research, 23(1), 1-30. https://doi.org/10.1506/axu4-q7q9-3yab-4qe0 
Benston, G. J., \& Hartgraves, A. L. (2002). Enron: What happened and what we can learn from it. Journal of Accounting and Public Policy, 21(2), 105-127. https://doi.org/10.1016/S0278-4254(02)00042-X

Budiarto, D. S., Yennisa, Y., \& Widyaningrum, R. (2018). Does Religiosity Improve Tax Compliance? An empirical research based from gender. Jurnal Dinamika Akuntansi, 10(1), 82-90. https://doi.org/10.15294/jda.v10i1.12997

Carmona, S., \& Ezzamel, M. (2006). Accounting and religion: A historical perspective. Accounting History, 11(2), 117-127. https://doi.org/10.1177/1032373206063109

Farhan, M., Helmy, H., \& Afriyenti, M. (2019). Pengaruh Machiavellian Dan Love Of Money Terhadap Persepsi Etika Penggelapan Pajak Dengan Religiusitas Sebagai Variabel Moderasi: Jurnal Eksplorasi Akuntansi, 1(1), 470-486. https://doi.org/10.24036/jea.v1i1.88

Habermas, J. (1983), Moralbewusstsein und kommunikatives Handeln, S. V., Frankfurt am Main, translated by Lenhardt, C. and Nicholsen, S. W. (1990) as M., \& Consciousness and Communicative Action, Polity Press, C. (1983). No Title. Moral Consciousness and Communicative Action, Polity Press, Cambridge.

Hidayatulloh, A., \& Mutingatun, N. (2020). Etika Uang Dan Kecurangan Pajak: Religiusitas Intrinsik, Religiusitas Ekstrinsik, Gender, Materialisme, Dan Cinta Uang Sebagai Variabel Moderasi. Jurnal Riset Akuntansi, 12(2), 1-15. https://doi.org/10.34010/jra.v12i2.2907

Indriasari, R. (2015). Ketika Sains [Akuntansi] Bertasbih Spirit Cinta. Jurnal Akuntansi Multiparadigma, 6(2), 316-326. https://doi.org/10.18202/jamal.2015.08.6025

Kamayanti, A. (2020). Vocational Accounting Education: Are We Producing Labours or Architects of Civilization? 136(Ambec 2019), 189-193. https://doi.org/10.2991/aebmr.k.200415.038

Mamik. (2015). Qualitative Methodology. East Java: Zifatama Publisher. Patton MQ. (1990). Qualitative evaluation and research methods. 2nd edition. London: Publikasi Sage.

McBarnett, D. and Whelan, C. (n.d.). No Title. The Elusive Spirit of the Law: Formalism and the Struggle for Legal Control”, in Freedman, J. and Power, M. (Eds), Law and Accountancy: Conflict and Co-Operation in the 1990s (1990), 80-105.

McKernan, J. F., \& Kosmala Maclullich, K. (2004). Accounting, love and justice. Accounting, Auditing \& Accountability Journal, 17(3), 327-360. https://doi.org/10.1108/09513570410545777

Moleong, L.J. 2011. Metodologi Penelitian Kualitatif. Bandung: PT Remaja Rosdakarya.

Rosianti, C., \& Mangoting, Y. (2014). Pengaruh Money Ethics Terhadap Tax Evasion Dengan Intrinsic Dan Extrinsic Religiosity Sebagai Variabel Moderating. Tax \& Accounting Review, 4(1), 1-11. 
Email : editorijhess@gmail.com

Shah, A. K. (1996). Creative compliance in financial reporting. Accounting, Organizations and Society, 21(1), 23-39. https://doi.org/10.1016/0361-3682(95)00015-2

Sugiyono. 2012. Statistika untuk Penelitian. Bandung: Alfabeta.

Basri, Y. M. (2014). Efek moderasi religuisitas dan gender terhadap hubungan etika uang dan kecurangan pajak. SNA 17 Mataram, Lombok, 1-23.

Wahyuni-TD, I. S., Fernando, Y., Hasnita, E., \& Hasnita, E. (2018). Role of Islamic Ethics Towards Ethical Accounting Practice. Journal of Governance and Integrity, 2(1), 23-27. https://doi.org/10.15282/jgi.2.1.2018.5535 